\title{
Adjunktpædagogikum med en international dimension
}

Karen M. Lauridsen, lektor, Center for Undervisning og Laering, Aarhus BSS, Aarhus Universitet.

Stacey M. Cozart, chefkonsulent, Center for Undervisningsudvikling og Digitale Medier, Arts, Aarhus Universitet.

Ole Lauridsen, lektor, Center for Undervisning og Loering, Aarhus BSS, Aarhus Universitet.

Annika Büchert Lindberg, specialkonsulent, Science and Technology Learning Lab, Science and Technology, Aarhus Universitet.

\section{Faglig artikel (bedømt af redaktionen)}

Denne artikel diskuterer udviklingen af adjunktpcedagogikum inden for rammerne af AU's internationaliseringsstrategi 2014 hvori det forudses at uddannelsernes indhold skal have en international dimension, og at der skal tages højde for de studerendes sproglige og kulturelle forskellighed i undervisningen. Det nuvœrende adjunktpadagogikum i to spor - et dansk og et engelsk - beskrives og diskuteres. På baggrund heraf fremlaegges og diskuteres et forslag til et alternativ der i højere grad kunne tage højde for internationaliseringsstrategiens intentioner og fremme samarbejde mellem adjunkterne på tvaers af deres sproglige og kulturelle forskelligheder. På denne måde ville adjunktpaedagogikum i højere grad afspejle de vilkår som galder for universitetets uddannelser i det hele taget, og styrke inklusionen af alle adjunkter på universitetet.

\section{Indledning}

På de danske universiteter og andre højere læreanstalter er der gennem de seneste totre årtier gennemført en række tiltag for at internationalisere uddannelsesudbuddet og tiltrække flere udenlandske studerende. Dette har betydet at der udbydes flere uddannelser eller uddannelsesmoduler end tidligere på engelsk, og netop valget af engelsk som undervisningssprog og antallet af internationale - eller mobile - studerende betragtes ofte som de primære karakteristika ved internationalisering. Ifølge Wächer \& Maiworm (2014) ligger Danmark da også på førstepladsen hvad angår omfanget af engelsksprogede programmer: 38\% af de danske bachelor- eller kandidatuddannelser udbydes på engelsk mod et europæisk gennemsnit på 5,7\% uden for Storbritannien og Irland; og omfanget af studerende indskrevet på disse programmer er 12,4\% mod et europæisk gennemsnit på 1,3\% (Wächter \& Maiworm, 2014, s. 43-45).

I denne artikel tager vi imidlertid afsæt i den litteratur om internationalisering af højere uddannelse hvor vi finder en bredere definition af begrebet idet den omfatter andre faktorer end uddannelsessprog og studentermobilitet, herunder bl.a. de kulturelle for- 
skelle blandt de studerende og deres forskelligartede uddannelsesbaggrund samt de profiler og læringsmål som defineres for uddannelserne (jf. nedenfor og de Wit el al., 2015; Leask, 2015). Denne bredere definition genfindes også i flere af universiteternes internationaliseringsstrategier, jf. fx Aarhus Universitet (2014).

For at underviserne kan håndtere virkeliggørelsen af sådanne strategier, vil de ofte have behov for pædagogisk-didaktisk kompetenceudvikling, også selv om de er ansat som lektorer eller professorer og har en mere omfattende undervisningserfaring (Lauridsen, under udgivelse). I det følgende vil vi dog koncentrere os om adjunktpædagogikum og de pædagogisk-didaktiske udviklingsbehov som adjunkterne har når de opnår ansættelse på en dansk højere læreanstalt. Med adjunktpædagogikum på Aarhus Universitet (AU) som case vil vi diskutere om disse behov i øjeblikket tilgodeses i tilstrækkeligt omfang. Herefter vil vi skitsere et alternativ til de eksisterende adjunktkurser baseret på en kombination af deltagerevalueringer, egne erfaringer og den nyeste litteratur på området.

\section{Internationalisering af højere uddannelse}

Før vi vender os mod undervisernes kompetenceudvikling, vil vi kort gøre rede for hvad vi forstår ved begrebet internationalisering. De Wit et al. (2015) har på basis af en større europæisk undersøgelse udvidet den hidtil gængse definition (Knight, 2004; Knight, 2012) af internationalisering i højere uddannelse, og vi vælger denne definition af to grunde: Dels opsummerer den status på forskningen inden for dette område, dels afspejler den en udvikling som kan observeres i universiteternes politikker og strategier, også selv om der ikke nødvendigvis er fuld overensstemmelse mellem sådanne strategier og den konkrete implementering af dem.

"IInternationalisation of Higher Education is] the intentional process of integrating an international, intercultural, or global dimension into the purpose, functions or delivery of post-secondary education, in order to enhance the quality of education and research for all students and staff, and to make a meaningful contribution to society" (udvidelserne er markeret med recte; de Wit et al., 2015, s. 29).

Det er her værd at lægge mærke til hvad der rent faktisk indgår i definitionen, men også hvad der netop ikke er med. Der tales om en international, interkulturel eller global dimension i uddannelsernes formål og undervisningsform for at styrke kvaliteten af uddannelse og forskning for alle studerende (både lokale og mobile), og for at kandidaterne kan yde et meningsfuldt bidrag til samfundet. Internationalisering gælder alle uddannelser og er ikke udelukkende et gode for den enkelte studerende, men i høj grad også for det samfund som kandidaterne skal virke i efter de har afsluttet deres uddannelse. 
Hvis man ser på hvad der ikke står i definitionen ovenfor, er det bemærkelsesværdigt at der ikke tales om mobilitet (undervisere eller studerende), og at undervisningssproget heller ikke nævnes her. Begge dele skyldes ganske enkelt at såvel mobilitet som sprogvalg anses for at være et af flere værktøjer i den værktøjskasse som i sin helhed udgør mulige måder at internationalisere på, og at man derfor sagtens kan forestille sig en internationaliseret uddannelse som udelukkende undervises af lokale undervisere for lokale studerende på det lokale sprog. Fag som politisk teori eller obstetrik kan eksempelvis uden videre gennemføres med en international dimension under sådanne betingelser - og bliver det måske også nogle steder. Men ofte kan man ikke se det i beskrivelsen af uddannelsen. Eksempelvis er politiske teorier ikke begrænset til et enkelt land, men er næsten per definition internationale eller måske i nogle tilfælde europæiske. Den sammenligning der sker mellem forskellige teorier på tværs af kulturelle (og nationale) grænser, bør i henhold til ovenstående definition således ekspliciteres i læringsmålene for et kursus i politisk teori. Et andet eksempel kunne være sundhedsuddannelserne hvor læger og sygeplejersker fx skal være forberedt på at håndtere de normer for ikke mindst fødsel og død som deres patienter kommer med, og tage højde (eller beslutte i hvilken grad de vil tage højde) for fremmedartede traditioner og normer på danske sygehusafdelinger. Den situation bør indgå som et scenarie i sundhedsuddannelserne (og gør det allerede flere steder). Det bør ligeledes være klart i læringsmålene for de pågældende uddannelser at kandidaterne har kendskab til sådanne forskelle i kulturelle normer og kan forholde sig professionelt til dem. Der er dermed også tale om at øge bevidstheden hos undervisere og studerende om den internationale dimension, bl.a. ved at tydeliggøre den i fag- og eksamensbeskrivelser.

Denne tydeliggørelse af den internationale dimension er en af hovedpointerne i Leasks idé om det internationaliserede curriculum (Leask, 2015). Mens nogle discipliner allerede vil have en tradition for en sådan international dimension, er der andre for hvilke der er tale om reel nytænkning. Men uanset hvad fagtraditionen er eller har været, vil der typisk være store forskelle mellem hvorledes internationaliseringen af curriculum konkretiseres i bestemte, faglige kontekster (Green \& Whitsed, 2015; Sawir, 2011).

I deres rapport understreger de Wit et al. (2015) den aktive rolle som både forskere, undervisere og administrativt personale skal spille i udviklingen af universiteternes internationalisering, ikke mindst på uddannelsesområdet:

"Academics, whose contribution over the past 25 years has been reduced in the increased centralisation of European programme administration, are now understood to play a crucial role in the internationalisation of education and research and need to be given additional support" (de Wit et al. 2015, s. 30).

Netop behovet for at styrke uddannelse eller efteruddannelse af underviserne for at sikre kvaliteten og kvalitetsudviklingen i de videregående uddannelser fremhæves også 
flere andre steder (fx Lauridsen \& Lillemose, 2015; Lauridsen, under udgivelse). I det følgende vil vi redegøre for og diskutere hvorledes denne støtte til underviserne gives eller kan gives i form af adjunktpædagogikum.

\section{Adjunktpædagogikum som obligatorisk kompetenceudvikling}

De danske universiteter skal som bekendt udbyde en universitetspædagogisk uddannelse til alle adjunkter (adjunktpædagogikum) så at de har de nødvendige undervisningsmæssige kvalifikationer til at kunne søge stilling som lektor i Danmark. Obligatorisk adjunktpædagogikum, eller i det hele taget et obligatorisk pædagogisk uddannelsesforløb, kendes kun i ganske få lande (jf. Fink, 2013), og det er derfor en overraskelse for de fleste adjunkter som er uddannet andre steder, at det er et krav at man har gennemført et sådant kompetenceudviklingsforløb for at opnå fastansættelse på et dansk universitet.

Det stigende antal udenlandske adjunkter i Danmark har de fleste steder givet anledning til at de ansvarlige for pædagogikumforløbene dels har revurderet og revideret indholdet af pædagogikum, dels har måttet forholde sig til om forløbene skulle gennemføres på dansk eller engelsk. Resultatet af denne proces synes at være væsentligt forskellig fra universitet til universitet: Nogle har valgt at gennemføre adjunktpædagogikum for alle adjunkter på engelsk mens andre har valgt at have et dansk og et engelsk spor, eventuelt med fælles valgmoduler på engelsk. Man kunne hævde at undervisningssproget i adjunktuddannelsen i sig selv kun er et spørgsmål om at alle deltagere i et givet kursus skal kunne kommunikere med hinanden, men hvis det betyder at man adskiller de danske og de udenlandske adjunkter i to spor, får det nogle uheldige konsekvenser. Det samme gælder hvis man samler alle i et engelsksproget adjunktpædagogikum uden at tage højde for deltagernes forskelligheder i programmets indhold og form. Vi vender tilbage til begge dele nedenfor.

\section{Case: Adjunktpædagogikum på AU}

På AU varetages adjunktpædagogikum af Universitetspædagogisk Netværk (UPNet). Det er et samarbejde mellem de fire universitetspædagogiske centre på universitetets fire hovedområder. Der gennemføres to dansksprogede og et engelsksproget forløb per år for adjunkter på tværs af hele universitetet. For nærværende er det et krav at de danske adjunkter følger det dansksprogede forløb, og at de udenlandske adjunkter følger det engelsksprogede forløb (Aarhus Universitet, ingen dato (1) og (2)).

Adjunktpædagogikum består af fire moduler som tilsammen udgør en arbejdsbelastning svarende til 5 ECTS (150 timer). De fire moduler omfatter introduktion til universitetspædagogik og -didaktik, undervisningsplanlægning og -metoder med udgangspunkt i Biggs \& Tang (2011), blended learning (Edu-IT) og udarbejdelse af undervisningsportfolioer. Desuden tilbydes adjunkterne ligesom alle andre undervisere forskellige supplerende kurser, workshops, mv. 
Det engelsksprogede adjunktpædagogikum var oprindeligt tænkt som en grundlæggende universitetspædagogisk uddannelse der bl.a. skulle udvikle adjunkternes kompetencer mhp. at undervise flerkulturelle grupper af studerende og sætte fokus på kulturforskelle for at udvikle undervisningskulturen på universitetet. Et af målene var således

"at fokusere på de kulturelle forskelle som en ressource for loering og udviklingen af undervisning og uddannelse, således at de "fremmedes" iagttagelse af den danske kontekst og sammenligning med egen baggrund udnyttes som et laringspotentiale frem for at "opdrage" til danske normer. AU skal således søge at udnytte de ressourcer udenlandske VIPer og studerende reproesenterer til at udvikle såvel undervisningskultur som faglig kultur" (Kruse, 2008).

Det engelsksprogede spor var altså i udgangspunktet forskelligt fra det danske, men efterfølgende besluttede ledelsen at alle adjunkter skulle gennemgå mere ensartede forløb, og at det engelsksprogede adjunktpædagogikum stort set skulle være en spejling af det danske. Man kan sige at de udenlandske adjunkter paradoksalt nok på en og samme gang er blevet inkluderet i den danske uddannelseskultur gennem det engelsksprogede adjunktpædagogikum, men samtidig er blevet udelukket fra samtalen med deres danske kolleger i forløbet, og at beslutningen ikke har bidraget til at styrke internationalisering af uddannelserne. Tværtimod har det ført til etableringen af to adskilte siloer - en med de danske og en med de udenlandske adjunkter.

På trods af beslutningen om at holde de to grupper adskilt i relativt ensartede forløb har det engelsksprogede program imødekommet de udenlandske adjunkters specielle behov, bl.a. ved at eksplicitere karakteristika ved danske studerende og dansk uddannelseskultur og ved et specielt udviklet delmodul om danske eksamensformer og eksamensafvikling. Dette er ikke mindst vigtigt for de udenlandske adjunkter som (på engelsk) underviser på enkeltmoduler eller vejleder på dansksprogede uddannelser der stort set udelukkende søges af danske studerende.

De tilpasninger der er foretaget i programmet for adjunktpædagogikum, har været begrundet dels i resultaterne af den forskning og udvikling som har fundet sted på dette område gennem de seneste år (hvor en stor del fx er samlet i Carroll, 2015), dels i de erfaringer som underviserne har opnået via egen undervisning samt ved deltagelse i flere udviklingsprojekter vedrørende internationalisering af undervisning (fx Lauridsen \& Lillemose, 2015; Lauridsen \& Cozart, 2015). Endelig er der sket ændringer som opfølgning på de systematisk gennemførte deltagerevalueringer, og selv om de to spor i udgangspunktet ser forholdsvis ensartede ud, har der alligevel udviklet sig en vis forskel mellem dem betinget af de to forskellige målgruppers behov.

På det mere personlige niveau har flere af de udenlandske adjunkter givet udtryk for at de synes det er givende at komme i kontakt med andre i samme situation som dem selv på tværs af universitetet. De udenlandske adjunkter er imidlertid en meget hetero- 
gen gruppe som derfor også har forskellige kompetenceudviklingsbehov. Baggrundsoplysninger på de adjunkter der deltog i kurset i efteråret 2015, viste bl.a. følgende ( $n$ = 42): De kom fra 25 forskellige lande og talte 20 forskellige førstesprog; nogle var kommet til Danmark få uger eller måneder før kursusstart, mens andre havde boet i landet i flere (op til 8) år. Nogle talte og underviste på dansk, mens andre først skulle til at begynde at lære sproget. Nogle skulle have deres første undervisning på AU i samme semester som de gennemførte adjunktkurset, mens andre havde undervist på AU i flere (op til 6) år. Hertil kommer at de havde en meget forskelligartet baggrund og erfaring med at bo i udlandet og dermed i en fremmed kulturel sammenhæng: 37 af de 42 havde således allerede arbejdet i mindst 3 måneder i mindst et andet land end deres hjemland før de kom til Danmark; flere af dem havde boet i 3-4 forskellige lande. På samme måde er der også afgørende forskelle mellem de danske adjunkter: Nogle af dem har en ganske omfattende erfaring med at forske eller undervise på ikke-danske universiteter, mens det kun gælder i begrænset omfang - eller slet ikke - for andre; beklageligvis foreligger der ikke data for de danske adjunkter på samme måde som for de udenlandske.

På trods af de betydelige forskelle inden for begge grupper af adjunkter er der gode argumenter for at blande dem på ét hold: På mange institutter underviser adjunkterne de samme grupper af studerende på dansk eller engelsk, og begge grupper af adjunkter underviser og vejleder blandede grupper af danske og udenlandske studerende på de engelsksprogede programmer. Det fremgår da også af deltagerevalueringerne at en del af de danske adjunkter gerne ville gennemføre pædagogikum sammen med de udenlandske kolleger som de underviser sammen med på institutterne.

Et forløb om undervisning på de engelsksprogede programmer med sprogligt og kulturelt forskelligartede studerende er fra 2015 blevet indført som et valgmodul på den dansksprogede uddannelse, men har været en obligatorisk del af det engelsksprogede spor gennem flere år. Nogle af de udenlandske adjunkter har vanskeligt ved at forstå hvorfor de skal have dette modul ("Det ved vi jo godt" lyder kommentarerne i evalueringerne). De pågældende ser ikke altid at dette kan være en udfordring for alle undervisere uanset baggrund. Ved at lade alle adjunkterne deltage i det samme kursus og arbejde sammen kunne de alle sammen i fællesskab opnå erfaring med undervisning og læring i tværkulturelle grupper hvilket ville afspejle situationen på de uddannelser som mange af dem underviser på. Tilsvarende ville de blandede grupper åbne mulighed for en højere grad af erfaringsudveksling som også kunne komme alle adjunkterne til gode. Dette gælder ikke mindst når det drejer sig om de principper for god undervisning som vi vender tilbage til i det næste afsnit.

\section{En alternativ organisation af adjunktpædagogikum}

Vi har allerede ovenfor henvist til flere af de positive effekter der ville være ved at slå alle adjunkter sammen på sprogligt og kulturelt blandede hold. I det følgende vil vi dis- 
kutere yderligere fordele - og mulige udfordringer - ved en sådan alternativ organisation af adjunktpædagogikum.

Med udgangspunkt i de Wit et al.s definition af internationalisering som vi præsenterede ovenfor, vil det være naturligt at alle adjunkter gennemgår et forløb hvor den internationale dimension i indhold og form er både et tema og et grundvilkår. Adjunktpædagogikum kunne på den måde være eksemplarisk for hvorledes undervisning på universitetet planlægges og gennemføres. Nedenstående forslag er dog på ingen måde begrænset til de aktuelle forhold på AU, men er oplæg til en mere generel diskussion som vil være relevant på alle danske højere læreanstalter der arbejder med den internationale dimension af uddannelserne.

En del af den eksisterende undervisning på adjunktpædagogikum ved Aarhus Universitet tager allerede udgangspunkt i de principper for god praksis som er blevet udviklet som en del af de projekter Betty Leask har stået i spidsen for i Australien (Leask, 2015). De samme principper genfindes hos Carroll (2015). I det følgende vil vi illustrere vores forslag ved hjælp af disse principper:

1) Focus on students as learners.

2) Respecting and adjusting for diversity.

3) Provide context specific information and support.

4) Good teaching across cultures will enable meaningful intercultural dialogue and engagement.

5) Be adaptable, flexible and responsive to evidence.

6) Preparing students for life in a globalised world.

Principperne kunne som udgangspunkt gælde al undervisning. Leask (2015; Appendix A) bruger dem til at illustrere hvad der kræves når de studerende skal arbejde sammen i flerkulturelle grupper (aktiv læring). Vi eksemplificerer dem her i relation til et pædagogikumforløb som omfatter både danske og udenlandske adjunkter. Idéen er at underviserne på adjunktpædagogikum skal tage højde for disse principper i tilrettelæggelsen og gennemførelsen af adjunktkurset på samme måde som adjunkterne anbefales at gøre det i deres egen undervisning.

1) Alle adjunkter er i gang med at udvikle sig som kompetente undervisere. Alle vil have behov for at lære noget nyt, men de har ikke alle sammen brug for at lære det samme: Eksempelvis har nogle brug for at udvikle sig som gode forelæsere, der kan engagere og inddrage alle i auditoriet; nogle har brug for at udvikle sig som vejledere, og nogle har brug for at vide mere om eksamensregler og den rolle de selv skal spille som eksaminator eller censor. 
2) Underviserne skal respektere og i deres undervisning tage højde for forskelligheder mellem de deltagende adjunkter. Som nævnt ovenfor har de fx et meget forskelligartet kendskab til det danske uddannelsessystem og den danske uddannelseskultur hvilket har betydning for deres forviden og det de kan bidrage med i adjunktkurset; desuden har det betydning for deres individuelle kompetenceudviklingsbehov.

3) Og netop fordi adjunkterne har en meget forskelligartet baggrund, skal underviserne sørge for at være meget eksplicitte i de informationer de giver, og i de krav de stiller til adjunkterne.

4) Den måde man tilrettelægger undervisning og ikke mindst gruppearbejde på, er afgørende for det udbytte som deltagerne får af det samlede kursus, og for deres mulighed for at lære af hinanden på tværs af kulturer og videreudvikle deres interkulturelle kompetencer. I adjunktpædagogikum har det vist sig meningsfuldt i nogle sammenhænge at blande adjunkterne på basis af deres kulturelle baggrund i flerkulturelle grupper; andre gange er det mere hensigtsmæssigt at blande dem på tværs af fag eller - lige omvendt - at sammensætte arbejdsgrupperne så adjunkter fra samme fag eller fagområder arbejder sammen. Lige meget hvad underviserne vælger, skal de grundlæggende principper forklares tydeligt for deltagerne.

5) Man skal som underviser udvikle sin evne til at kunne afvige fra sin egen planlægning og tilpasse undervisningen til den respons som man oplever i undervisningslokalet - eller til de evalueringer af undervisningen som bliver gennemført.

6) Indholdet i adjunktpædagogikum skal kunne udnyttes af deltagerne, også hvis de får ansættelse på et andet universitet. Adjunkterne arbejder i en globaliseret verden, og den pædagogisk-didaktiske bagage vi som undervisere giver dem med, skal de kunne bruge uanset hvor de efterfølgende bliver ansat i deres karriereforløb.

Nogle vil måske mene at principperne er ret indlysende - eller endda banale, men vores egen erfaring er at de giver anledning til udbytterige diskussioner og interaktion med og mellem deltagerne på adjunktpædagogikum. Og der hvor vi allerede har prøvet at anvende dem, tilkendegiver flere i deres evalueringer at de efterfølgende har kunnet bruge principperne i deres egen undervisning og undervisningstilrettelæggelse.

Selv om man fokuserer på de indholdsmæssige, kulturelle og didaktiske forhold i Leasks principper, er det også nødvendigt at forholde sig til undervisningssproget. Hvis alle skal gennemføre samme forløb, skal det være på engelsk fordi ikke alle udenlandske adjunkter vil kunne deltage i et kursus hvor der undervises på dansk. Men der vil til gengæld også være danske adjunkter som ikke umiddelbart vil føle sig til rette i en engelsksproget sammenhæng. Man kunne dog argumentere for at man som universitets- 
ansat i Danmark i 2016 skal kunne begå sig på engelsk, og at alle modulerne i adjunktpædagogikum derfor burde udbydes på engelsk. Det er den løsning som flere danske universiteter allerede har valgt, også selv om de ikke alle i indhold og form har taget højde for de kulturelle og pædagogisk-didaktiske forskelle i adjunkternes baggrund. En løsning kunne være at gennemføre hele forløbet samlet eller med samme læringsmål, men med nogle moduler eller delmoduler på dansk og/eller engelsk.

Skiftet fra dansk til engelsk i ét fælles kursus for alle har dog ikke kun implikationer for deltagerne. Det berører i høj grad også underviserne på adjunktpædagogikum ligesom det berører alle undervisere på universitetet når instituttet og studienævnet beslutter at ændre undervisningssproget. Der vil derfor være nogle som har behov for en opkvalificering af deres engelskkompetencer; og alle skal være opmærksomme på den betydning det har for deltagerne/de studerende når de skal lære via et fremmedsprog (jf. fx Tange, 2010; Tange, 2015). Det er typisk mere tidskrævende (de studerende - og også mange af deres undervisere - læser langsommere og skriver langsommere på engelsk), og det er i det hele taget vanskeligere at lære gennem et fremmedsprog end det er at lære på sit modersmål (jf. fx også Carroll, 2015).

Hele diskussionen om undervisernes sprogkompetencer har indtil for nylig været et af de problemer ved internationalisering som nok var der, men ikke i tilstrækkelig grad blev taget alvorligt. I de seneste år er det dog blevet tydeligt at flere og flere universiteter i Danmark og andre steder indfører eller har indført sprogtest for de medarbejdere som skal undervise på engelsk. Center for Undervisning og Parallelsproglighed på Københavns Universitet har længst erfaring med dette og har også kunnet validere deres certificering (Dimovà \& Kling, 2015). Hvis en sådan sprogtest gøres obligatorisk, skal den naturligvis også gælde for dem som underviser på adjunktpædagogikum, ligesom de skal have adgang til støtte og udvikling af deres sprogfærdighed når eller hvis det er nødvendigt. Men man skal i den sammenhæng være opmærksom på at rene sprogtests som ikke også inddrager pædagogisk/didaktiske og kulturelle forskelligheder i det internationale læringsrum, kun i begrænset omfang tester de færdigheder som er nødvendige når man skal undervise på et fremmedsprog (engelsk) til meget sprogligt og kulturelt forskelligartede grupper af studerende hvoraf kun et lille mindretal har engelsk som førstesprog.

\section{Konklusion}

Vi har ovenfor med udgangspunkt i de Wit et al.s definition af internationalisering i højere uddannelse og i Leasks principper for god undervisningspraksis argumenteret for at adjunktpædagogikum skal afspejle de vilkår som allerede gælder - eller kommer til at gælde - for en ikke ubetydelig del af universitetets bachelor- og kandidatuddannelser hvor indholdet har en international dimension, og hvor de didaktiske valg af undervisnings- og læringsformer skal tilgodese de studerendes sproglige og kulturelle forskelle og de udfordringer som det byder de studerende og deres undervisere. 
Et sådant indhold og en sådan form for adjunktpædagogikum vil imødekomme de læringsbehov som adjunkterne har og - i stigende grad - vil have når de danske universiteter skal (videre-)udvikle kvaliteten af de uddannelser som de udbyder til både lokale og mobile studerende.

Karen M. Lauridsens er lektor og hendes udviklings- og forskningsaktiviteter centrerer sig om undervisning og loering i international uddannelse, herunder uddannelse på engelsk. Hun har i 2012-2015 koordineret et Erasmus Akademisk Netvaerk om dette emne IntlUni. The challenges of the multilingual and multicultural learning space in the international university. KML underviser bl.a. på den engelsksprogede version af adjunktpaedagogikum på Aarhus Universitet.

Stacey M. Cozart er chefkonsulent og arbejder inden for universitetspoedagogik med sarlig fokus på undervisning og loering i internationale uddannelser herunder uddannelseskompetencer på engelsk. Udover at undervise inden for disse områder, bl.a. på det engelsksprogede adjunktpaedagogikum på Aarhus Universitet, har hun voeret involveret $i$ flere danske og internationale forsknings- og udviklingsprojekter vedr. internationalisering af højere uddannelser.

Ole Lauridsen er lektor og koordinerer og underviser på den engelsksprogede version af adjunktpaedagogikum på Aarhus Universitet og forestår kurser for ph.d.-studerende ved Aarhus BSS. Derudover varetager han mange sparrings- og supervisionsopgaver på fakultetet. På forskningssiden arbejder han med hjernen og laering samt effekten af en saerlig komprimeret form for supervision: 'supermentoring'.

Annika Büchert Lindberg er specialkonsulent og ph.d. i Biologi og arbejder med Science Education. Hun underviser ph.d.-studerende samt adjunkter i undervisning og loering med et scerligt fokus på aktiverende science undervisning, blended learning og educational IT. Fra 2012-2015 var hun desuden projektleder for den International Biologiolympiade, som Aarhus Universitet var voert for i 2015.

\section{Litteratur}

Aarhus Universitet. (2014). Internationalisation Strategy 2014-2020. http://www.au.dk/fileadmin/www.au.dk/Thomson/int-strategi_FINAL_WEB.pdf (09.05.2016).

Aarhus Universitet. (Ingen dato - 1). Adjunktkursus. http://upnet.au.dk/adjunktkursus/ (09.05.2016).

Aarhus Universitet. (Ingen dato - 2). Teacher Training Programme in English. http://upnet.au.dk/teacher-training-programme-in-english/ (09.05.2016)

Biggs, J. \& Tang, C. (2011). Teaching for Quality Learning at University. $4^{\text {th }}$ ed. Buckingham: Open University Press/McGrawHill. 
Carroll, J. (2015). Tools for Teaching in an Educationally Mobile World. New York and London: Routledge.

Dimová, S. \& Kling, J. (2015). Lecturers' English proficiency and university language policies for quality assurance. I R. Wilkinson \& M. L. Walsh (red.): Integrating Content and Language in Higher Education: From Theory to Practice. Selected Papers from the 2013 ICLHE Conference. Frankfurt: Peter Lang, 50-65.

Fink, L. D. (2013). The Current State of Faculty Development Internationally. International Journal for the Scholarship of Teaching and Learning, 7(2).

Green, W. \& Whitsed, C. (red.) (2015). Critical Perspectives on Internationalising the Curriculum in Disciplines. Reflective Narrative Accounts from Business, Education and Health. Rotterdam: Sense Publishers.

Knight, J. (2004). Internationalization Remodeled: Definition, Approaches, and Rationales. Journal of Studies in International Education, 8(1).

Knight, J. (2012). Concepts, Rationales, and Interpretive Frameworks in the Internationalization of Higher Education. In Deardorff, D.K. et al. (2012). The SAGE Handbook of International Higher Education (27-42). Thousand Oaks: Sage.

Kruse, S. (2008). Møde om pædagogisk kursus for udenlandske medarbejdere ved AU 27. juni 2008. Aarhus Universitet. Upubliceret referat.

Lauridsen, K. M. (under udgivelse). Professional development of international classroom lecturers. I J. Valcke \& R. Wilkinson (red.): Integrating Content and Language in Higher Education: Perspectives on Professional Practice. Selected Papers from the IV International Conference Integrating Content and Language in Higher Education 2015. Frankfurt: Peter Lang.

Lauridsen, K. M. \& Lillemose, M. K. (red.) (2015). Opportunities and challenges in the multilingual and multicultural learning space. Final document of the Int/Uni Erasmus Academic Network project 2012-15. Aarhus: IntIUni. http://intluni.eu/uploads/media/The_opportunities_and_challenges_of_the_MM LS_Final_report_sept_2015.pdf. (09.05.2016).

Leask, B. (2015). Internationalizing the Curriculum. Internationalization in Higher Education Series. Abingdon: Routledge.

Sawir, E. (2011). Academic staff response to international students and internationalizing the curriculum: the impact of disciplinary differences. International Journal for Academic Development, 16(1). DOI:

10.1080/1360144X.2011.546224.

Tange, H. (2010). Caught in the Tower of Babel: university lecturers' experience with internationalisation. Language and Intercultural Communication, 10(2). DOI: 10.1080/14708470903342138

Tange, H. (2015). International undervisning. I L. Rienecker \& P. Stray Jørgensen (red.): Universitetspcedagogiske praksisser. Frederiksberg: Samfundslitteratur, 121-134. 
Wächter, B. \& Maiworm, F. (red.) (2014). English-Taught Programmes in European Higher Education. The State of Play in 2014. ACA Papers on International Cooperation in Education. Lemmens.

De Wit, H., Hunter, F., Howard, L. \& Egron-Polak, E. (2015). Internationalisation of Higher Education. Study requested by the European Parliament's Committee on Culture and Education.

http://www.europarl.europa.eu/RegData/etudes/STUD/2015/540370/IPOL_STU (2015)540370_EN.pdf(09.05.2016). 